\title{
Kajian Implementasi Rencana Kedaruratan Nuklir Kanada untuk Mendukung Rencana Pembangunan Sistem Kedaruratan Nuklir Nasional
}

\author{
AKHMAD KHUSYAIRI, M.Eng *, WERDI PUTRA DAENG BETA, SKM, M.Si ** \\ * Pusat Pengkajian Sistem dan Teknologi Pengawasan Instalasi dan Bahan Nuklir BAPETEN \\ ** Direktorat Inspeksi Fasilitas Radiasi dan Zat Radioaktif BAPETEN \\ J1. Gajah Mada no 8 Jakarta, Email : a.khusyairi@bapeten.go.id,
}

\begin{abstract}
Abstrak-Kajian Implementasi Rencana Kedaruratan Nuklir Kanada Untuk Mendukung Rencana Pembangunan Sistem Kedaruratan Nuklir Nasional. Kajian implementasi rencana kedaruratan nuklir Kanada meliputi studi laporan dan kajian awal kedaruratan, pengaktifan struktur pendukung nasional, dan implementasi rencana kedaruratan nuklir federal Kanada. Aktivasi struktur pendukung nasional, meliputi tingkat pengaktifan struktur pendukung nasional dan hubungan dengan CNSC (Canadian Nuclear Safety Commission). Dalam implementasi tersebut diidentifikasi para pihak pemangku kepentingan yang terkait (stakeholders), penentuan tingkat kedaruratan nuklir yang mungkin terjadi dan rencana antisipasi dan ketersediaan dukungan infrastruktur yang terkait. Selain itu dalam kajian ini dibahas dan dibandingkan kesiapan implementasi rencana kedaruratan nuklir di Indonesia setelah DPR memutuskan energi nuklir bukan lagi sebagai energi alternatif dalam bauran energi nasional pada awal tahun 2014. Kajian ini dilakukan dengan menggunakan metode studi literature.
\end{abstract}

Kata kunci: kedaruratan nuklir, Kanada, Kecelakaan nuklir, CNSC

\begin{abstract}
Canadian Nuclear Emergency Plan Implementation Assessment to Support Development on National Nuclear Emergency System. Assessment on implementation of the nuclear emergency plan includes initial emergency reports and studies, activation of national support structure, and implementation of the federal nuclear emergency plan. Activation of national support structure, including the activation level of national support structure and coordination with the CNSC (Canadian Nuclear Safety Commission). It has been identified in the implementation of the relevant stakeholders in the level of nuclear emergency that may occur and mitigation plan and the availability of infrastructure. On the other hand, this assessment discussed and compared the readiness of nuclear emergency plan implementation in Indonesia after Parliament decided nuclear energy is no longer an alternative energy in the national energy mix in early 2014. The study was performed using the method of literature study.
\end{abstract}

Keywords: nuclear emergency, Canada, nuclear accident, CNSC

\section{PENDAHULUAN}

Kedaruratan nukir adalah suatu keadaan bahaya yang dapat mengancam keselamatan manusia, kehilangan harta benda dan atau kerusakan lingkungan, yang berasal dari dan diakibatkan oleh kecelakaan nuklir atau kecelakaan radiasi. Sedangkan tanggap darurat nuklir adalah serangkaian kegiatan yang dilaksanakan dengan segera dalam kejadian kedaruratan nuklir yang bertujuan mengurangi dampak serius terhadap manusia, harta benda dan lingkungan [6].

Terkait dengan kedaruratan nuklir di Kanada, operator PLTN, reaktor riset atau fasilitas nuklir lainnya bertanggungjawab terhadap rencana kesiapsiagaan dan tanggap darurat nuklir di dalam kawasan (on-site). Pemerintah propinsi memiliki tanggung jawab utama untuk melindungi kesehatan dan keselamatan masyarakat, harta benda dan lingkungan dalam batas wilayah kewenangannya.

Sedangkan pemerintah federal bertanggungjawab terhadap pengembangan, pengendalian dan peraturan pengawasan tenaga nuklir untuk tujuan damai, mengelola pertanggungjawaban kerugian nuklir dan berkoordinasi dan menyediakan dukungan untuk pemerintah propinsi dalam tanggap darurat nuklir. Wilayah tanggap darurat pemerintah federal diantaranya adalah [5]:

- wilayah daratan, program dan layanan terkait

- kedaruratan yang berdampak pada lebih dari satu propinsi atau wilayah teritorial,
- menjadi wakil Negara dalam komunitas internasional,

- koordinasi dukungan internasional untuk kedaruratan di Kanada,

- menjadi juru bicara dalam misi diplomatik Kanada,

- membantu rakyat Kanada yang berada di luar negeri, dan

- berkoordinasi dengan organisasi tanggap darurat nasional jika terjadi kedauratan nuklir di luar negeri.

Perencanaan tanggap darurat terhadap kedaruratan nuklir lepas kawasan (off-site) menjadi tanggung jawab bersama antara pemerintah propinsi dan pemerintah federal. Tanggung jawab Pemerintah federal berdasarkan pendekatan semua potensi bahaya/kerugian ("all-hazards" approach). [5].

\section{TUJUAN}

Kajian ini ditujukan untuk mengidentifikasi sisi implementasi kedaruratan nuklir di Kanada dan keterkaitan kesiapan rencana kedaruratan nuklir di Indonesia.

3. METODE

Metode kajian adalah sudi literatur dari berbagai sumber.

\section{TINJAUAN PUSTAKA}

Tenaga nuklir, disamping memberikan manfaat terdapat potensi bahaya yang terkandung dibalik pemanfaatannya. Dalam pemanfaatan tenaga nuklir khususnya untuk pembangkit listrik, produk fisi merupakan salah satu hal yang harus diantisipasi agar tidak terjadi pelepasan ke lingkungan. 
hal ini disebabkan oleh selain aktivitasnya yang tinggi juga umur paroh dari produk fisi tersebut sangat panjang.

Kedaruratan nuklir adalah keadaan bahaya yang mengancam keselamatan manusia, kerugian harta benda atau kerusakan lingkungan hidup, yang timbul sebagai akibat kecelakaan nuklir atau kecelakaan radiasi[2]. Setiap Negara yang memiliki fasilitas nuklir, baik reaktor penelitian maupun reaktor daya harus memiliki rencana kedaruratan nuklir nasional. Dalam system kedaruratan nuklir Kanada, Pemerintah propinsi dapat memiliki rencana kedaruratan nuklir tingkat propinsi. Rencana Kedaruratan Nuklir Tingkat Propinsi akan dijalankan setelah konsultasi dan kesepakatan antara Koordinator nasional, Pemerintah propinsi dan pejabat federal di daerah [5]

Kedaruratan digolongkan menjadi Kedaruratan lokal, kedaruratan fasilitas, kedaruratan tapak dan kedaruratan umum [3], yang termasuk dalam kedaruratan lokal diantaranya adalah terdeteksinya simptom medis akibat paparan radiasi, kehilangan sumber radioaktif, pencurian sumber radioaktif berbahaya, penemuan sumber radioaktif berbahaya tak bertuan. Sedangkan kejadian yang termasuk dalam kedaruratan fasilitas adalah kecelakaan yang melibatkan kegagalan atau kerusakan parah sehingga diperlukan tingkat proteksi lebih terhadap orang-orang yang berada di fasilitas dan dibutuhkan tindakan mitigasi untuk melindungi personil dalam skala fasilitas.

Sedangkan kejadian yang termasuk dalam kedaruratan tapak adalah kecelakaan pada fasilitas yang melibatkan kegagalan atau kerusakan parah pada tingkat proteksi untuk masyarakat tapak dan di sekitarnya yang membutuhkan tindakan mitigasi untuk melindungi masyarakat di sekitar tapak dan tindakan perlindungan pada off-site jika diperlukan.

Sedangkan kejadian yang termasuk kedaruratan umum adalah kecelakaan pada fasilitas yang melibatkan lepasan materi radioaktif dan paparan radiasi yang membutuhkan UPZ (Urgent Protective Zone) di off-site.

\section{PEMBAHASAN}

\subsection{Laporan dan Kajian Awal Kedaruratan}

Ketika kedaruratan terjadi pada fasilitas nuklir Kanada, maka Organisasi Tanggap Kedaruratan Propinsi dan Badan Pengawas Nuklir Kanada (CNSC) yang pertama kali menerima laporan awal mengani kedaruratan tersebut. Jika kedaruratan terjadi di luar Kanada, maka Kementerian Kesehatan Kanada, CNSC, KLH dan Kemlu dan Perdagangan Internasional Kanada, Kantor Kesiapsiagaan Nuklir dan Proteksi Infrastruktur atau badan federal lainnya mendapatkan informasi awal dari mitra mereka atau melalui organisasi internasional

Jika terjadi kedaruratan radiologi serius lainnya, maka baik Pemerintah federal maupun Pemerintah propinsi dapat menerima informasi dari mitra mereka, melalui organisasi internasional atau melalui sistem penyebaran informasi lainnya yang telah ditetapkan.

Jika diperoleh informasi kedaruratan, maka badan federal atau Organisasi Tanggap Kedaruratan Propinsi harus memberi kabar kepada nomor telepon 24 jam Kantor Kesiapsiagaan Nuklir yang berada dalam koordinasi Kementerian Kesehatan (Kemenkes) Kanada dalam waktu paling lama 2 jam setelah laporan awal. Kemenkes Kanada akan meneruskan dan menyebarkan informasi tersebut kepada mitra federal terkait lainnya yang ada dalam Rencana Kedaruratan Nuklir Federal bahwa telah terjadi kedaruratan nuklir dan memerlukan langkah tindak lanjut. Kemenkes Kanada juga memberi informasi kepada personil yang bertanggungjawab/ditunjuk dalam Pusat Bantuan Nasional dan Organisasi Regional Federal. Ketika aktivasi, maka para personil tersebut memberitahukan ke organisasi asal mereka dan segera menuju lokasi pusat operasi kedaruratan.

Sedangkan menurut penulis, di Indonesia, laporan kajian awal kedaruratan dilaksanakan oleh Koordinator Tanggap Darurat di BAPETEN. Laporan kajian awal ini dilakukan sehubungan dengan adanya kejadian yang menjurus timbulnya dampak radiasi, kondisi paparan radiasi dan atau kontaminasi yang melampaui batas keselamatan. Pada tahap ini, status aktivasi satuan tanggap darurat pada posisi siaga dan waspada.

\subsection{Aktivasi Struktur Dukungan Nasional}

Wewenang untuk mengaktifkan Struktur Pendukung Nasional berada di tangan Koordinator Nasional atau didelegasikan ke lembaga atau badan organisasi yang ditunjuk. Staf yang terlibat dan organisasi yang tercantum dibawah ini akan menerima informasi apakah semua atau sebagian struktur dukungan nasional diaktifkan pada waktu dan lokasi yang ditentukan. Para staf dan organisasi tesebut adalah sebagai berikut.

1. Pejabat yang ditunjuk dari Pusat Dukungan Nasional dan Organisasi Regional Federal;

2. Kantor Dewan Penasehat dan kontak resmi personil yang terdaftar dalam Rencana Kedaruratan Nuklir Federal (FNEP);

3. Institusi federal dan organisasi non-pemerintah yang terkait;

4. Organisasi Tanggap Darurat Propinsi setempat; dan

5. Pusat Koordinasi Operasi Kedaruratan Pemerintah (GEOCC).

Setiap departemen dan agen federal akan bertanggung jawab untuk memberitahukan kantor regionalnya. Ketika Pusat Dukungan Nasional telah beroperasi, maka secara berkala informasi akan disampaikan kepada pihak asing (Pemerintah Negara tetangga atau dunia internasional) dan organisasi internasional tentang kondisi terkini kedaruaratan yang sedang terjadi. Prosedur aktivasi khusus dimasukkan dalam prosedur darurat FNEP. Fungsi koordinasi ini merupakan tanggung jawab Pemeritah federal guna memberikan informasi dan melakukan koordinasi dalam menjalankan kegiatan tanggap darurat dengan Pusat Dukungan Nasional dan Organisasi Regional federal melalui pejabat yang ditunjuk.

\subsection{Tingkat Aktivasi Struktur Dukungan Nasional}

Tingkat Aktivasi Struktur Dukungan Nasional akan tergantung pada faktor-faktor seperti karakteristik, besar dan lokasi kejadian, wilayah yang terdampak nyata atau wilayah yang berpotensi terkena dampak, dan pada tingkat keterlibatan federal diperlukan. Tingkat aktivasi tersebut diantaranya adalah [5]:

1. Tingkat Pemantauan, beberapa pejabat yang ditunjuk yang berasal dari Pusat Dukungan Nasional akan ditugaskan untuk memantau situasi. Para personil kedaruratan akan bekerja dalam kondisi normal atau dari pusat operasi kedaruratan masing-masing departemen mereka masing-masing, sesuai dengan rencana kedaruratan di departemen mereka masing-masing. Petugas Perwakilan Federal dan teknisi spesialis dari 
Organisasi Federal Regional dapat diterjunkan untuk melaksanakan tindakan pemantauan sesuai dengan rencana kedaruratan nuklir Propinsi atau Rencana Kedaruratan Nuklir Tingkat Propinsi dalam FNEP tersebut.

2. Tingkat Aktivasi Parsial, beberapa Pejabat yang ditunjuk yang berasal dari Struktur Dukungan Nasional akan diaktifkan dan diinstruksikan untuk berkumpul di pusatpusat kedaruratan yang terdekat. Koordinator Nasional secara berkala akan mengkaji kembali situasi untuk menentukan apakah diperlukan aktivasi penuh Struktur Dukungan Nasional atau tidak.

3. Tingkat Aktivasi Penuh: semua pejabat/petugas yang ditunjuk yang berada dalam Struktur Dukungan Nasional diaktifkan dan diinformasikan untuk berkumpul di pusatpusat kedaruratan yang tepat. Rencana kedaruratan yang relevan, prosedur, dan pusat-pusat kedaruratan departemen dan badan-badan federal diimplementasikan dan petugas penghubung semuanya diaktifkan secara serentak dengan Pusat Dukungan Nasional dan Pusat Kedaruratan Regional. Operasi bantuan besar-besaran ke Propinsi biasanya akan berlangsung dalam tingkat Aktivasi Penuh. Antarmuka antara pemerintah federal dan pemerintah propinsi secara spesifik dan hubungan organisasi manajemen antara kedua keadaan darurat di bawah Kendali Aktivasi diilustrasikan secara umum dalam Gambar 2.

\subsection{Hubungan dengan Canadian Nuclear Safety Commission (CNSC)}

Ketika darurat nuklir terjadi di Kanada di fasilitas nuklir/PLTN berlisensi, maka Komisi Keselamatan Nuklir Kanada (CNSC) diberitahukan oleh fasilitas yang terkena dampak, dan dapat diwakili oleh organisasi manajemen kedaruratan tingkat Propinsi. Setelah Struktur Dukungan Nasional diaktivasi, maka selanjutnya hubungan antara Pusat Dukungan Nasional dan CNSC ditetapkan di bawah FNEP, yang bergantung pada tingkat aktivasi:

1. Pemantauan : Pada tingkat ini, Koordinator Nasional atau otoritas yang mewakilinya akan mengadakan dan memelihara hubungan dengan Pusat Operasi Kedaruratan CNSC melalui Koordinator Perwakilan CNSC lepas kawasan.

2. Aktivasi Parsial atau Aktivasi Penuh : Staf Teknis CNSC akan bergabung dengan Kelompok Penasehat Teknis di Pusat Dukungan Nasional untuk berhubungan dengan pusat operasi darurat CNSC dan Staf CNSC dalam kelompok teknis Propinsi. Seorang pejabat CNSC akan bergabung dengan Satuan Urusan Publik (Public Affairs Group) di Pusat Dukungan Nasional untuk bekerja sama dengan Koordinator Informasi Publik CNSC.

Sementara itu kondisi Indonesia, pada tingkat pemantauan, menurut penulis, pihak fasilitas atau penguasa instalasi atau pemegang izin berkoordinasi dengan Ruang Tanggap Darurat (RTD) BAPETEN. Koordinasi antara pihak fasilitas dan RTD BAPETEN ini diperlukan untuk memantau parameter-parameter keselamatan operasi fasilitas secara online dan secara terus menerus. Sedangkan aktivasi parsial atau aktivasi penuh Satuan Tanggap Darurat (STD) Indonesia bergantung pada apakah kedaruratan itu berupa kedaruratan fasilitas atau kedaruratan umum.

\subsection{Implementasi Rencana Kedaruratan Nuklir Federal}

Implementasi rencana kedaruratan nuklir federal di Kanada tercantum dalam FNEP Master Plan. Otoritas untuk pelaksanaan FNEP harus diberikan kepada Menteri Kesehatan (atau Pimpinan Menteri alternatif yang ditunjuk oleh Kantor Dewan Penasehat) , Perdana Menteri Kanada atau Kabinet. Implementasi rencana darurat departemen dan prosedurnya tetap di bawah kendali masing-masing departemen atau instansi. Sesuai dengan keadaan spesifik darurat nuklir, keputusan untuk melaksanakan FNEP akan dibuat baik bersamaan dengan atau setelah aktivasi Struktur Dukungan Nasional. Koordinator Nasional dapat berkonsultasi dengan otoritas terkait lainnya mengenai persyaratan untuk melaksanakan semua atau sebagian dari FNEP tersebut. Konsultasi ini mungkin memerlukan aktivasi semua atau bagian dari Struktur Dukungan Nasional sebelum memutuskan pelaksanaan FNEP tersebut. Jika Struktur Dukungan Nasional belum diaktifkan , Koordinator Nasional akan memastikan bahwa Organisasi Tanggap Darurat Propinsi dan departemen federal dan lembaga yang bersangkutan diberitahu tentang keputusan untuk melaksanakan atau tidak melaksanakan FNEP.

Untuk kondisi Indonesia, implementasi rencana kedaruratan nuklir federal tidak ada. Akan tetapi, yang ada adalah implementasi rencana kedaruratan nuklir nasional yang mengacu pada Sistem Kesiapsaiagaan Nuklir Nasional (SKNN). SKNN diimplementasikan jika terjadi kedaruratan umum.

\subsection{Implementasi Rencana Kedaruratan Nuklir Tingkat Propinsi}

Pelaksanaan Rencana Utama FNEP tidak secara otomatis menerapkan Rencana Kedaruratan Nuklir Tingkat Propinsi. Biasanya, Rencana Kedaruratan Nuklir Tingkat Propinsi akan dilaksanakan setelah konsultasi dan kesepakatan antara Koordinator nasional, pemerintah propinsi dan pejabat federal di daerah.

Untuk kondisi Indonesia, implementasi rencana kedaruratan nuklir tingkat propinsi adalah rencana kedaruratan nuklir lokal.

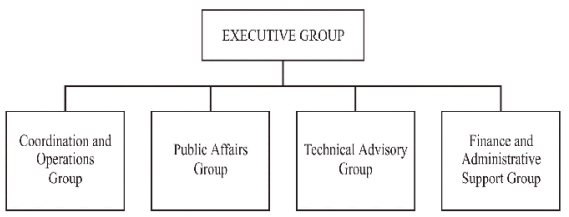

Gambar 1: Struktur Kelompok Pusat Dukungan Nasional[5]

Tabel 1: Susunan tim dalam Pusat Dukungan Nasional [5]

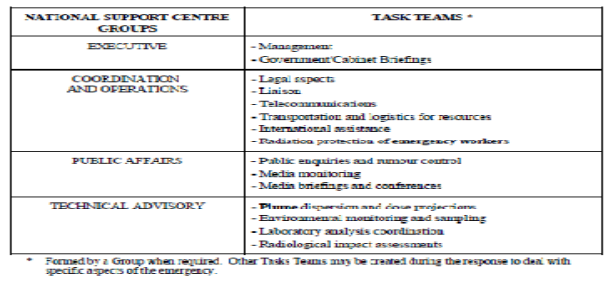




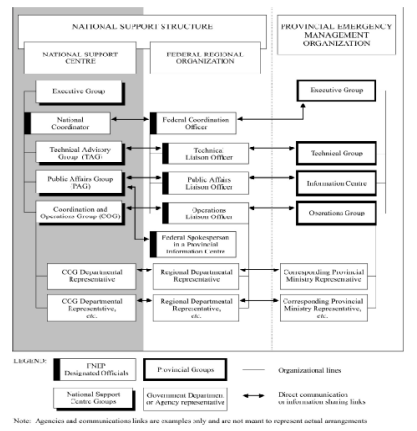

Gambar 2: Contoh Antarmuka Organisasi

Kedaruratan antara Pemerintah Propinsi dan Federal[5]

\subsection{Implementasi Rencana Kedaruratan Nuklir BAPETEN, Indonesia}

BAPETEN memiliki tanggung jawab dalam menyiapkan formulasi kebijakan teknis untuk melaksanakan dan mengembangkan rencana system kesiapsiagaan darurat nuklir nasional[1]. Berdasarkan Pasal 1 poin 7 dalam acuan [2] dinyatakan bahwa: kesiapsiagaan nuklir adalah serangkaian kegiatan yang terencana dan sistematik untuk mengantisipasi kedaruratan nuklir dengan menyediakan infrastruktur dan kemampuan melaksanakan fungsi mitigasi untuk mengatasi kedaruratan nuklir secara cepat, tepat, efektif dan efisien.

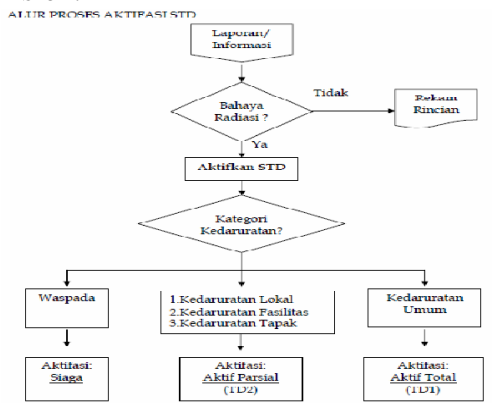

Gambar 3. Alur Proses Aktivasi Satuan Tanggap Darurat (STD) BAPETEN [3]

Sebagaimana CNSC Kanada, BAPETEN juga mengenal aktivasi penuh/aktivasi total dan aktivasi parsial[3]. Pada aktivasi penuh, tim tanggap darurat BAPETEN berupaya melaksanakan mitigasi jangka pendek sampai jangka menengah terhadap kecelakaan nuklir atau radiologi [3][8]. Aktivasi total terhadap tim tanggap darurat BAPETEN dalam Kedaruratan Umum (tingkat tertinggi dalam kedaruratan nuklir, termasuk kedaruratan nuklir Pembangkit Listrik Tenaga Nuklir, PLTN) bertujuan untuk mengantisipasi kemungkinan situasi yang memburuk dan mengumpulkan semua informasi dan laporan. Kedaruratan umum sebagaimana dijelaskan dalam acuan adalah kedaruratan yang terjadi dari ancaman kategori I (termasuk kedaruratan PLTN). Kedaruratan Umum mengakibatkan terjadinya resiko pelepasan zat radioaktif lepas kawasan atau paparan radiasi, sehingga perlu ditetapkan tindakan perlindungan segera di lepas kawasan (urgent protective Zone (UPZ) off-site).

Tindakan dalam UPZ pada saat kedaruratan nuklir atau radiologi adalah evakuasi, dekontaminasi individu, menetapkan lokasi pengungsian, pemberian perlindungan pernapasan (masker), tablet iodine dan pelarangan konsumsi bahan pangan yang berpotensi terkontaminasi dalam perencanaan pembatasan makanan yang terpantau terusmenerus dan menyediakan instruksi perlindungan produk pertanian.

Sedangkan untuk aktivasi parsial ditujukan untuk mengantisipasi kedaruratan nuklir lokal, (tingkat propinsi), kedaruratan fasilitas dan kedaruratan tapak.

Penulis yakin jika kesiapan implementasi rencana kedaruratan nuklir di Indonesia terpelihara dengan baik maka akan dapat mendukung program kebijakan energi nuklir setelah DPR memutuskan energi nuklir bukan lagi sebagai energi alternatif dalam bauran energi nasional pada awal tahun 2014 [4]

\section{Kesimpulan}

Kajian Implementasi Rencana Kedaruratan Nuklir Kanada sangat penting sebagai bahan pembanding rencana kesiapsiagaan nuklir di BAPETEN untuk mendukung kebijakan dan program energi nuklir ke depan. Selain itu sangat diperlukan adanya koordinasi antar instansi dalam penanggulangan kedaruratan nuklir. Selanjutnya dengan kemampuan koordinasi yang saling mendukung satu sama lain maka diharapkan dapat menjadi dasar pengembangan dan penguatan infrastruktur organisasi ketanggap daruratan di tingkat nasional yang handal dan siap melindungi masyarakat, pekerja dan lingkungan hidup.

\section{Daftar Pustaka}

[1.] Bapeten. (2004). Keputusan Kepala Badan Pengawas Tenaga Nuklir Nomor : 01 Rev.2/K-Otk/V - 04 Tentang Organisasi Dan Tata Kerja Badan Pengawas Tenaga Nuklir. Jakarta: Bapeten.

[2.] Bapeten. (2010). Peraturan Kepala Badan Pengawas Tenaga Nuklir Nomor 1 Tahun 2010 Tentang Kesiapsiagaan Dan Penanggulangan Kedaruratan Nuklir. Jakarta: Bapeten.

[3.] Bapeten. (2007). Peraturan Kepala Badan Pengawas Tenaga Nuklir Nomor 14 Tahun 2007 Tentang Satuan Tanggap Darurat. Jakarta: Bapeten.

[4.] Energy Today. (2014, January 23). DEN-Komisi VII Setujui Rancangan Kebijakan Energi Nasional. Retrieved March 24, 2014, from Energy Today: http://energitoday.com/2014/01/23/den-komisi-viisetujui-rancangan-kebijakan-energi-nasional/

[5.] Health Canada . (2002). Federal Nuclear Emergency Plan. Ontario: Health Canada .

[6.] IAEA. (2002). Safety Standard Series No. GS-R-2, Preparedness and Response for a Nuclear or Radiological Emergency. Vienna: IAEA.

[7.] INTERNATIONAL ATOMIC ENERGY AGENCY. (2003). Method for Developing Arrangements for Response to a Nuclear or Radiological Emergency, Updating IAEA-TECDOC-953, EPR-METHOD . Vienna: IAEA.

[8.] Khusyairi, A. a. (2011). European Union Nuclear Emergency Preparedness Study on Sustainable Restoration and Long-term Management of Radioactive Contaminated Rural, Urban and Industrial Ecosystems (STRATEGY). International Conference on Global Resources Conservation. Malang: Universitas Brawijaya. 